\title{
Effect of phytoaccumulation of arsenic and chromium on structural and ultrastructural changes of brake fern (Pteris vittata)
}

\author{
Balaji B. Maruthi Sridhar ${ }^{1 *}$, Fengxiang X. Han ${ }^{2}$, Susan V. Diehl ${ }^{3}$, David L. Monts ${ }^{4,5}$ and Yi Su ${ }^{4}$ \\ ${ }^{1}$ Department of Environmental Science and Technology, Texas Southern University, Houston, TX 77004 \\ ${ }^{2}$ Department of Chemistry and Biochemistry, Jackson State University, Jackson, MS 39217 \\ ${ }^{3}$ Department of Forest Products, Mississippi State University, Mississippi State, MS 39762 \\ ${ }^{4}$ Institute of Clean Energy \& Technology (ICET), Mississippi State University, Mississippi State, MS 39762 \\ ${ }^{5}$ Department of Physics and Astronomy, Mississippi State University, Mississippi State, MS 39762 \\ * Corresponding Author: 403Y, New Science Center; Department of Environmental Science and Technology; Texas \\ Southern University, Houston, TX 77004; Tel.: (713) 313-1388, Fax: (713) 313-1853; email: bhaskarm@tsu.edu \\ Received: 06 September 2010; Accepted: 30 0ctober 2011
}

\begin{abstract}
Structural and ultrastructural changes caused by bioaccumulation of As and $\mathrm{Cr}$ in brake fern (Pteris vittata), a known arsenic hyperaccumulator, were investigated. Potted plants of brake fern were exposed to metal treatments of As and Cr for three weeks. Leaf, stem and root samples were collected periodically and fixed for LM (Light Microscopy), SEM (Scanning Electron Microscopy) and TEM (Transmission Electron Microscopy) to evaluate anatomical changes. The fresh weights, dry weights, RWC (Relative Water Content) and plant heights were obtained before the brake fern plants were harvested for metal accumulation analysis. The As accumulated mainly in the shoots while $\mathrm{Cr}$ accumulated mainly in the roots of the metal-treated plants. Significant changes in the ferns physical characters, including fresh weight, dry weight, RWC, and plant height were observed for only Cr-treated plants but not for As-treated plants. Microscopic studies reveal the $\mathrm{Cr}$ accumulation resulted in dehydration and collapse of internal structure of leaves and cellular breakdown of roots. The As-treated plants showed no significant structural changes in leaves, stems and roots compared to control plants. Clotted depositions were observed in roots and stems of plant groups treated with highest concentration of $\mathrm{Cr}$ and As when compared to control (TO) group. Our study indicates that $\mathrm{Cr}$ has a profound impact on physiology and structure of fern plants. The accumulation of $\mathrm{Cr}$ resulted in decrease in growth rate, total biomass and RWC. We believe that brake fern plants can uptake, translocate and sequester As because it caused no significant structural changes in leaves, stems and roots of the plants.
\end{abstract}

Key words: Anatomy, arsenic, chromium, hyperaccumulator, microscopy, phytoremediation, Pteris vittata, translocation, ultrastructure

Abbreviations: LM: Light Microscopy; SEM: Scanning Electron Microscopy; FAA: Formaldehyde Acetic acid; RWC: Relative Water Content; LSD: Least Significant Difference

\section{INTRODUCTION}

Chromium and Arsenic are serious metal contaminants in soil, sediments and ground water (Bartlett, 1991; Witmer et al., 1991; Han et al., 2003). Many remedial measures have been directed towards the cleanup of $\mathrm{Cr}$ - and As-contaminated soils. One environmentally friendly and low cost approach is phytoremediation, which is the use of various plants to degrade, extract, contain or immobilize contaminants from soil and water (Raskin and Ensley, 2000). Phytoextraction of metals is 
mainly limited by low metal bioavailability in soil and poor metal translocation from roots to shoots (Blaylock and Huang, 2000). The bioavailability of metals in soil is strongly influenced by soil $\mathrm{pH}$ and complexation with ligands. $\mathrm{Cr}$ availability for plant uptake depends on the oxidation state of $\mathrm{Cr}$, $\mathrm{pH}$, presence of colloidal binding sites and Cr-organic complexes in soil (Losi et al., 1994).

Decreasing soil pH and the addition of soil amendments can enhance metal solubility, but they are limited by the tolerance of the plant to acid conditions or by excess leaching of the metals to the ground water (Blaylock and Huang, 2000). Also plant species differ significantly in metal uptake, distribution and tolerance. Some of these limitations can be overcome by using metal hyperaccumulators, which can accumulate high concentrations of metals in shoot tissues. These metal accumulators show a remarkable degree of selectivity in accumulating only specific metals from the substrate (Salt and Kramer, 2000), as in As hyperaccumulation by brake fern plants (Pteris vittata) (Ma et al., 2001). Also the ability of plants to hyperaccumulate one metal may infer some ability to accumulate other metals (Reeves and Baker, 1984). Hence in this study fern plants are also being evaluated for phytoextraction of $\mathrm{Cr}$.

The shoot/root ratios of metal concentrations of hyperaccumulators are always higher than non-hyperaccumulators (Salt and Kramer, 2000), as hyperaccumulators possess efficient root-to-shoot translocation. Baker (1981) suggested that metal hyperaccumulators always have shoot/root ratios greater than one while non-hyperaccumulators have ratios less than one. Recent studies have evaluated a large number of plant species for uptake and accumulation of $\mathrm{Cr}$ : Water hyacinth (Lytle et al., 1998), smart weed (Qiu et al., 1999), Arabidopsis thaliana (Salt et al., 1998), sunflower (Shahandeh and Hossner, 2000; Mei et al., 2002), Indian mustard (Salt et al., 1995; Shahandeh and Hossner, 2000), kale, cauliflower, cabbage (Zayed et al., 1998) and soybean (Mei et al., 2002). Salt et al. (1995) evaluated Thlaspi caerulescens, a hyperaccumulator of $\mathrm{Zn}$, and found that it did not accumulate $\mathrm{Cr}$.

Cr concentration in plants from published studies is always higher in roots than shoots. In other words, there is no known hyperaccumulators for $\mathrm{Cr}$. This has been attributed to a lack of internal transport of $\mathrm{Cr}$ (Shahandeh and Hossner, 2000; Han et al., 2004). Plants are known to uptake and reduce $\mathrm{Cr}$ (VI) to $\mathrm{Cr}$ (III) inside the plant tissues. This conversion of $\mathrm{Cr}$ is supposed to take place in roots soon after plant uptake (Zayed et al., 1998). However at the cellular level both $\mathrm{Cr}$ (VI) and $\mathrm{Cr}$ (III) are toxic to plants. $\mathrm{Cr}(\mathrm{VI})$ is a strong oxidizing agent and causes severe damage to cell membranes (Barcelo et al., 1986; Vazquez et al., 1987; Shahandeh and Hossner 2000;
Mei et al., 2002). $\mathrm{Cr}$ (III) is toxic to plants because of its ability to form complexes with nucleic acids, proteins and organic compounds. Barcelo et al. (1988) suggested that increased metal accumulation resulted in low cellular differentiation and thickenings in vascular bundles of bush bean stems. The foliar changes included breakdown of chloroplasts and decline in chlorophyll synthesis in bush bean plants (Barcelo et al., 1988) and reduction in the size of mesophyll cells in Arabidopsis halleri (Zhao et al., 2000). The structural and ultrastructural changes in plant cells caused by bioaccumulaion of metal have resulted in altered plant metabolism and growth.

The objectives of our study were to identify the structural and ultrastructural changes caused by $\mathrm{Cr}$ and As accumulation in leaves, stems and roots of break fern; and to evaluate brake fern plants for phytoremediation of $\mathrm{Cr}$. Light micrographs and electron micrographs of leaf, stem and root samples collected during the phytoremediation process are presented here to demonstrate anatomical changes. Biomass, RWC (Relative Water Content) and metal concentrations of plants are used to evaluate physiological changes caused by metal accumulation. We also monitored the changes in different plant characteristics of fern plants throughout the metal accumulation process using non-destructive and non-invasive plant spectral reflectance techniques. The results of the spectral study were reported in Sridhar et al. (2007a).

\section{MATERIAL AND METHODS}

Plant culture and phytoremediation experimental design: The phytoremediation experiment was conducted in fall 2002. Brake fern plants of 4-5 months age were obtained from Edenspace (Edenspace Inc., Dulles, VA). The plants were transplanted into plastic pots, each containing approximately $1.0-\mathrm{kg}$ of potting mix with one plant in each pot. The transplanting was done two weeks before starting the phytoremediation experiment. The soil used for the pot study was Miracle-Gro Potting Mix from Miracle-Gro Lawn Products Inc. (Marysville, $\mathrm{OH}$ ). Plants were kept outdoors in an enclosed area except during extreme weather conditions. Nutrient solution was supplied to the plants daily, starting one week after transplanting. The composition of the nutrient solution was 0.5 $\mathrm{mM} \mathrm{Ca}\left(\mathrm{NO}_{3}\right)_{2}, 3.1 \mathrm{mM} \mathrm{NH}_{4} \mathrm{NO}_{3}, 0.01 \mathrm{mM} \mathrm{KH}_{2} \mathrm{PO}_{4}, 50.0 \mu \mathrm{M}$ $\mathrm{KCl}, 0.2 \mu \mathrm{M} \mathrm{CuSO}_{4}, 12.0 \mu \mathrm{M} \mathrm{H}_{3} \mathrm{BO}_{4}, 0.1 \mu \mathrm{M} \mathrm{NiSO}_{4} \bullet 6 \mathrm{H}_{2} \mathrm{O}, 2.0$ $\mu \mathrm{M} \mathrm{MnSO}{ }_{4} \bullet \mathrm{H}_{2} \mathrm{O}, 0.5 \mu \mathrm{M} \mathrm{ZnSO}{ }_{4} \cdot 7 \mathrm{H}_{2} \mathrm{O}$, and $0.2 \mathrm{mM} \mathrm{MgSO}_{4}$. The plant treatment groups were supplied with $100 \mathrm{ppm}$ (AsT1) and $300 \mathrm{ppm}$ (AsT2) arsenic in the form of $\mathrm{Ca}_{3}\left(\mathrm{AsO}_{4}\right)_{2}$; and $300 \mathrm{ppm}$ (CrT1) and $600 \mathrm{ppm}$ (CrT2) chromium in the form of 
$\mathrm{K}_{2} \mathrm{Cr}_{2} \mathrm{O}_{7}$. All the treatment groups along with control (untreated, TO) were arranged in a completely randomized design with five replicates in each group. The metal treatments were applied at the rate of $50 \mathrm{ml} \mathrm{pot}^{-1}$ day $^{-1}$ starting at the $14^{\text {th }}$ day after transplanting. The plants were treated with metal solutions for 22 days and then were harvested. The metal treatments were supplemented with nutrient solution and water to avoid any water and nutrient deficiencies.

Procedures for microscopic study: Leaf samples $5 \mathrm{~mm}$ in length were excised from the middle portion of the leaflets of the upper fronds. Stem and root samples $5 \mathrm{~mm}$ in length were excised from $2 \mathrm{~cm}$ above and $2 \mathrm{~cm}$ below the stem-root intersection, respectively. The leaf, stem and root samples were prepared for light microscopy (LM), scanning electron microscopy (SEM) and transmission electron microscopy (TEM).

Light microscopy (LM): LM samples were immediately fixed in formaldehyde-acetic acid (FAA). The plant samples were alcohol dehydrated, paraffin embedded and ultramicrotomed. Leaf samples were subjected to different stains. Stains included copper sulfate for arsenic and Chrome Azurol S (CAS) for Cr in order to localize the respective metal in the plant tissues, and $1 \%$ toluidine blue and safranin $(0.1 \%)$ - fastgreen $(0.2 \%)$ to observe the structural changes (Sass, 1958).

For copper sulfate staining, the leaf, stem and root samples were excised and quickly immersed in FAA containing $10 \%$ formalin and $2.5 \%$ CuSO $_{4} .5 \mathrm{H}_{2} \mathrm{O}$ for 5 days. The samples were prepared for embedding by dehydrating in an ethanol series followed by citrisolve. The samples embedded in paraffin were microtomed to obtain $4 \mu$ sections and placed on glass slides. The slides along with sections were cleaned in citrisolve and dehydrated in an ethanol series to remove the paraffin. The sections were further counter stained with $2 \%$ safranin and then dehydrated and mounted (Pearse, 1972).

For Chrome Azurol $S$ (CAS) staining, LM sections embedded in paraffin were microtomed to obtain $4 \mu$ sections and placed on glass slides which were then cleared in citrisolve and dehydrated in an ethanol series. The sections were treated in $0.2 \%$ CAS solution for 24 hours at room temperature. The sections were then washed in a methanol series, dehydrated and mounted (Suzuki et al., 1978).

Scanning electron microscopy (SEM): Leaf stem and root samples were also prepared for scanning electron microscopy (SEM). Stem samples of approximately $5 \mathrm{~mm}$ in length were collected from $2 \mathrm{~cm}$ above the stem-root intersection. The procedure for collection of leaf and root samples was the same as described for LM. All the samples were immediately fixed in $2.5 \%$ glutaraldehyde in $0.05 \mathrm{M}$ potassium phosphate buffer $(\mathrm{pH}$ 7.1) for 8hrs (Sass, 1958; Johansen, 1940) and then dehydrated in an ethanol series. The samples were sealed in parafilm, frozen in liquid nitrogen and fractured transversely using a pre-cooled knife. The cryofractured specimens were critical point dried through carbon dioxide, mounted on stubs and coated with goldpalladium. All materials were observed with a LEO SEM.

Transmission electron microscopy (TEM): Leaf and stem segments of approximately $3 \mathrm{~mm}$ in length were collected for transmission electron microscopy (TEM). The samples were fixed in $2.5 \%$ glutaraldehyde in $0.05 \mathrm{M}$ potassium phosphate buffer ( $\mathrm{pH}$ 7.1) for 8hrs and post fixed with $\mathrm{OsO}_{4}$. The samples were dehydrated in an ethanol series and embedded in Spurrs epoxy resin. Ultrathin sections were obtained using an ultramicrotome and stained with uranyl acetate and basic lead citrate for observation using a JEOL TEM (Johansen, 1940).

Chemical analysis: The plants were cut about $2 \mathrm{~cm}$ above the soil at the end of the pot study. The harvested shoots and roots were dried at $80^{\circ} \mathrm{C}$ in an oven for 48 hours. Dry shoots were then ground and weighed. Plant samples (approximately $0.5 \mathrm{~g}$ ) were digested with concentrated $\mathrm{HNO}_{3}$ and $\mathrm{H}_{2} \mathrm{O}_{2}$ (Jackson, 1958; Han and Banin, 1997; Sridhar et al. 2007a, 2007b). The digested solution was filtered and then analyzed for As and $\mathrm{Cr}$ concentration using inductively coupled plasma-atomic emission spectrometry (ICP-AES).

Measurements and statistical analysis: The plant heights from the root-stem intersection to the growing tip of the stem were measured at the end of the experiment. The fresh weights and dry weights of the shoots were obtained using an electronic balance before and after drying in an oven. The RWC (Relative Water Content) of the plants were obtained using the formula (Fresh weight - Dry weight)/ Fresh weight. The leaf thicknesses were obtained by measuring light micrographs of all the replicates in each of the control (TO), AsT2- and CrT2- treated groups.

Statistical analysis was conducted with SAS statistical software (SAS Institute Inc. NC). The GLM procedure was used for analysis of different metal treatments with means separated by Duncan's multiple range test at $p<0.05$. The CORR procedure was used for correlation analysis with means separated at $p<0.05$.

\section{RESULTS}

Chemical analysis: Metal accumulation in plant shoots and roots increased significantly with an increase 
in applied metal solution concentration in both As(Table 1) and Cr- (Table 2) treated groups. The metal concentrations remained high in roots compared to shoots in Cr-treated groups, while metal content was higher in shoots than roots in As-treated groups. The ratios of shoot/root ratios were calculated to indicate the translocation efficiency of As and $\mathrm{Cr}$ from root to shoot. The shoot/root ratios were greater than one for As-treated plants (Table 1), indicating that plants have a high As uptake efficiency.

Table 1. Averaged As accumulation in shoot and root (in $\mathrm{mg} \mathrm{kg}^{-1} \mathrm{dry}$ weight), Shoot/root ratio, fresh weight, dry weight, relative water content (RWC), height and cellular width of leaves of plants treated with $A s(n=5)$ at the end of the experiment.

\begin{tabular}{ccccccccc}
\hline Treatment & Shoot & Root & Shoot/Root & Fresh.wt $(\mathrm{g})$ & Dry.wt $(\mathrm{g})$ & RWC $(\%)$ & Height $(\mathrm{cm})$ & Leaf Thickness $(\mu \mathrm{m})$ \\
\hline T0 & $18 \mathrm{c}^{*}$ & $20 \mathrm{c}$ & 0.91 & $19.30 \mathrm{a}$ & $4.15 \mathrm{a}$ & $78.34 \mathrm{a}$ & $21.6 \mathrm{~b}$ & 176.3 \\
AsT1 & $4952 \mathrm{~b}$ & $1229 \mathrm{~b}$ & 4.02 & $19.46 \mathrm{a}$ & $4.10 \mathrm{a}$ & $78.75 \mathrm{a}$ & $28.2 \mathrm{ab}$ & - \\
AsT2 & $8206 \mathrm{a}$ & $2282 \mathrm{a}$ & 3.59 & $18.16 \mathrm{a}$ & $3.82 \mathrm{a}$ & $78.75 \mathrm{a}$ & $24.0 \mathrm{a}$ & 180.5 \\
\hline
\end{tabular}

* Means followed by different letters are significantly different at the 0.05 probability level, grouped into classes $a, b$ and $c$.

Table 2. Averaged $\mathrm{Cr}$ accumulation in shoot and root (in $\mathrm{mg} \mathrm{kg}^{-1} \mathrm{dry}$ weight), shoot/root ratio, fresh weight, dry weight, relative water content (RWC), height and cellular width of leaves of plants treated with $\mathrm{Cr}(\mathrm{n}=5)$ at the end of the experiment.

\begin{tabular}{ccccccccc}
\hline Treatment & Shoot & Root & Shoot/Root & Fresh.wt $(\mathrm{g})$ & Dry.wt $(\mathrm{g})$ & RWC $(\%)$ & Height $(\mathrm{cm})$ & Leaf Thickness $(\mu \mathrm{m})$ \\
\hline T0 & $14 \mathrm{~b}^{\star}$ & $21 \mathrm{~b}$ & 0.67 & $19.30 \mathrm{a}$ & $4.15 \mathrm{a}$ & $78.34 \mathrm{a}$ & $21.6 \mathrm{a}$ & 176.3 \\
CrT1 & $921 \mathrm{~b}$ & $4610 \mathrm{a}$ & 0.19 & $16.38 \mathrm{a}$ & $4.10 \mathrm{a}$ & $74.20 \mathrm{ab}$ & $25.8 \mathrm{a}$ & - \\
CrT2 & $2108 \mathrm{a}$ & $7686 \mathrm{a}$ & 0.27 & $13.52 \mathrm{a}$ & $3.64 \mathrm{a}$ & $71.44 \mathrm{~b}$ & $22.2 \mathrm{a}$ & 150.9 \\
\hline
\end{tabular}

* Means followed by different letters are significantly different at the 0.05 probability level, grouped into classes $\mathrm{a}, \mathrm{b}$ and $\mathrm{c}$.

The $\mathrm{Cr}$ concentration is higher in roots than shoots (Table 2), hence the shoot/root ratios were less than one for Cr-treated plants. Even though the $\mathrm{Cr}$ concentration of shoots and roots of Cr treated plants is higher compared to control (T0), the extent of metal accumulation and uptake efficiency of $\mathrm{Cr}$ was lower than that of As. Chlorosis was not visually observed during the treatment process. General effects of $\mathrm{Cr}$ treatment included stunted growth with an increase in metal concentration. For Astreated plants, the growth rate was not significantly affected.

The averaged fresh weight and dry weight of the plants showed a decrease in AsT2 (Table 1) and CrT2 (Table 2) groups compared to Control (T0). The RWC of the plants was not significantly different in As-treated plants but showed a significant $(p<0.05)$ decreasing trend with an increase in $\mathrm{Cr}$ concentration (Table 2). The plants heights recorded at the end of the experiment showed no specific trend with accumulation of either metal (Table 1 and Table 2). The leaf thickness was obtained from the light micrographs decreased for CrT2- plants (Table 2) while it increased in AsT2- plants (Table 1).

Correlations between the metal accumulation in shoots and roots to the physical and anatomical characters of the plants were analyzed. Among the fresh and dry weights of shoot, only the fresh weight of $\mathrm{Cr}$ - treated plants showed a significant negative correlation $(p<0.05)$, with an increase in $\mathrm{Cr}$ accumulation in roots (Table 3). The Relative Water Content (RWC) of the plants showed a significant negative correlation with $\mathrm{Cr}$ concentration in the roots $(p<0.001)$ and shoots $(p<0.05)$ while no significant correlation was found in As-treated plants (Table 3 ). The leaf thickness was negatively correlated with shoot and root concentration for $\mathrm{Cr}$, but only at 0.06 probability level (Table 3 ). No such correlations were observed in As-treated plants.

Table 3. Correlation coefficients between metal concentrations in shoot and root of plants and physical and anatomical characters: fresh weight, dry weight, relative water content (RWC), height of the plants and cellular width of the leaves.

Significant levels: * significant at 0.05 probability level, ${ }^{*}$ significant at 0.001 probability level.

\begin{tabular}{ccccc}
\hline $\begin{array}{c}\text { Physical/ } \\
\text { Anatomical } \\
\text { Characteristics }\end{array}$ & $\begin{array}{c}\text { As shoot } \\
\text { conc. }\end{array}$ & $\begin{array}{c}\text { As root } \\
\text { conc. }\end{array}$ & $\begin{array}{c}\text { Cr shoot } \\
\text { conc. }\end{array}$ & Cr root conc. \\
\hline Fresh. Wt (g) & -0.06 & -0.17 & -0.38 & $-0.58^{\star}$ \\
Dry. Wt $(\mathrm{g})$ & -0.11 & -0.20 & -0.17 & -0.45 \\
RWC $(\%)$ & 0.14 & 0.04 & $-0.62 *$ & $-0.84^{\star *}$ \\
Height $(\mathrm{cm})$ & 0.31 & 0.31 & -0.07 & 0.03 \\
Width $(\mu \mathrm{m})$ & 0.10 & 0.07 & -0.51 & -0.61 \\
\hline
\end{tabular}


Structural changes: For As- treated plants, there were no significant changes in the internal structure of leaves compared to the control group (Figure 1A). The AsT2-treated leaves appeared healthier with well-developed epidermal and mesophyll cells (Figure 1B) compared to control group in SEM micrographs. The Cr-treated plants showed significant foliar structural changes compared to the control group (T0). The SEM micrographs from the CrT2 leaf samples showed reduction in epidermal and palisade cell size and decrease in intercellular spaces and break down of cells (Figure $1 \mathrm{C}$ ) compared to the control group (Figure 1A).

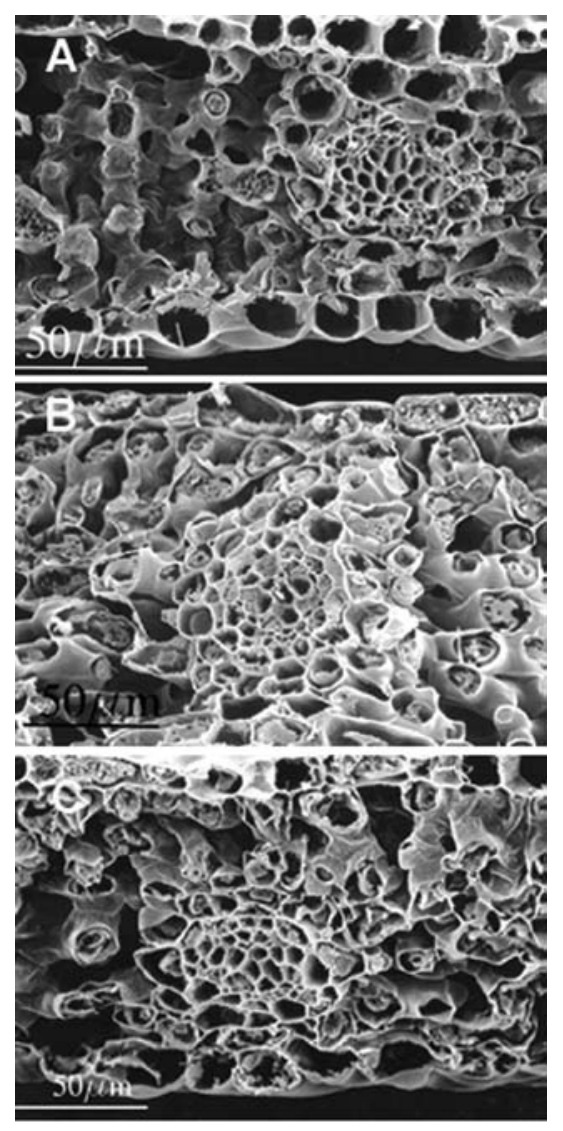

Figure 1. SEM micrographs showing transverse section of control (A), AsT2(B) and CrT2- (C) treated leaves. No significant changes were observed in AsT2 (B) treated leaves compared to control-T0 (A). The CrT2- (C) treated leaves showed breakdown of palisade and epidermal cells with an increase in $\mathrm{Cr}$ concentration.
The TEM micrographs of AsT2-treated leaves showed well developed chloroplasts with minimum structural changes in both upper and lower palisade cells (Figure 2B) compared to the control group (TO). The only notable structural change observed for leaves of AsT2-treated plants, was the loss of the spindle shape in the chloroplasts of the lower mesophyll cells (Figure 2B) compared to the control (Figure 2A).

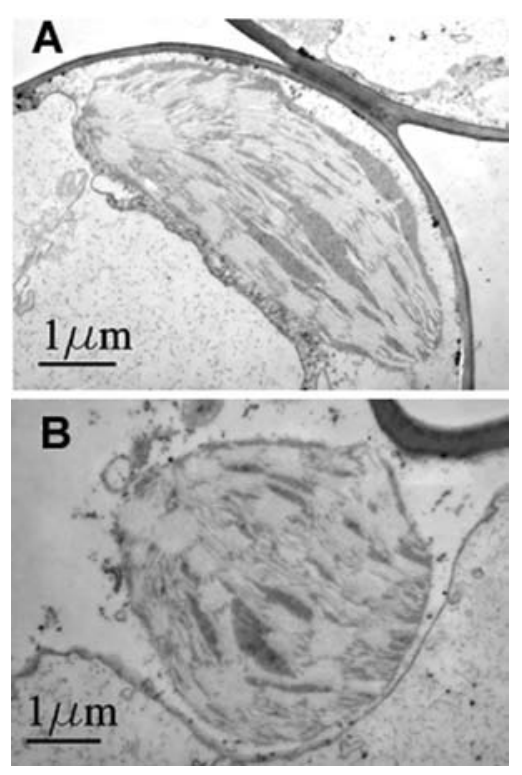

Figure 2. TEM micrographs showing the chloroplast of lower palisade parenchyma cells of AsT2-(B) treated fern leaves compared to the control-T0 (A). Note the loss of spindle shape (B) in chloroplast with an increase in As concentration compared to control group-T0 (C).

Light micrographs of AsT2-treated stems (Figure 3B) showed granular As precipitates along the walls of xylem and phloem vessels compared to control (T0) stems (Figure 3A). The transverse sections of the stems were pretreated with $\mathrm{CuSO}_{4}$ to precipitate the metal contents. Similarly the sections of CrT2-treated leaves were stained with CAS (Chrome Azurol S) to localize the $\mathrm{Cr}$ by staining $\mathrm{Cr}$ blue. The leaves showed intensely stained blue colored areas in vascular bundles of midrib in CrT2-treated leaves (Figure 3D) compared to control leaves (Figure $3 \mathrm{C}$ ). 

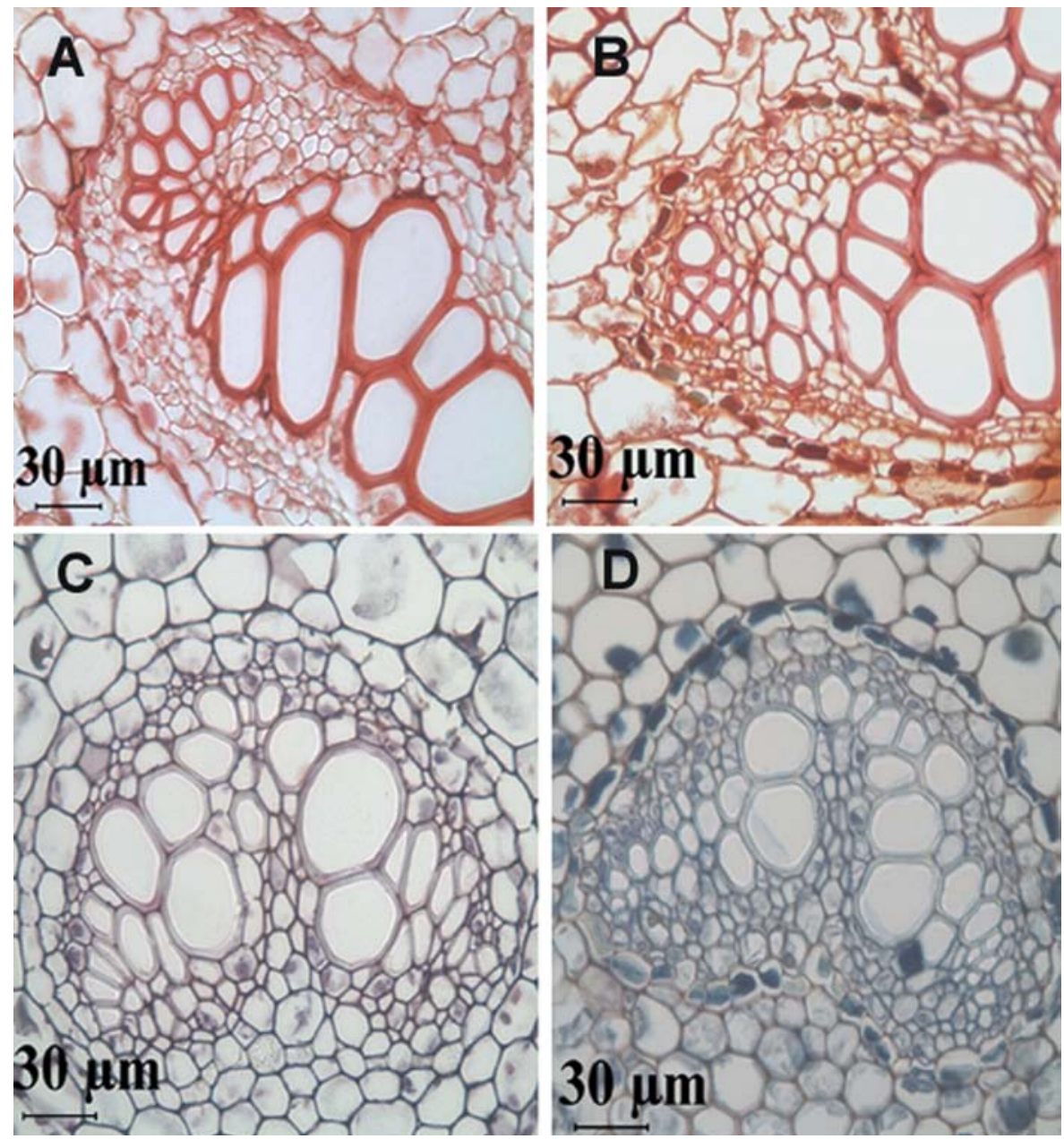

Figure 3. Light micrographs showing the transverse section of stem $(A, B)$ and midrib of leaf $(C, D)$. The stems show precipitates of As surrounding the vascular bundles of stems (B) compared to control stems (A). The stems were treated with $\mathrm{CuSO}_{4}$ to localize As. The leaf midribs showed areas stained with blue surrounding the vascular bundles in $\mathrm{Cr}$ treated leaves (D) compared to control (C). The leaves were treated with CAS to localize $\mathrm{Cr}$.

The SEM micrographs of stem cross sections of AsT2treated plants (Figure 4B) showed clotted depositions along the walls of xylem and phloem vessels compared to control group (Figure 4A). The depositions were also seen in roots of AsT2-treated plants (Figure 4D) but were less intense compared to the stems (Figure 4B). No such depositions were seen in stems and roots of control plants (Figure $5 \mathrm{~A}$ and Figure $5 \mathrm{C}$ ). The SEM micrographs of stems of CrT2- (Figure
5B) treated plants showed thickened cell walls and a decrease in the lumen size of xylem and phloem vessels. No such thickenings were observed in control stems (Figure 5A). The roots showed precipitates (Figure $5 \mathrm{D}$ ) all along the walls of vascular bundles compared to the control (Figure $5 \mathrm{C}$ ). The light micrographs of CrT2-treated roots showed breakdown of cortex and endodermal cells (Figure 5F) compared to the control group (Figure 5E). 


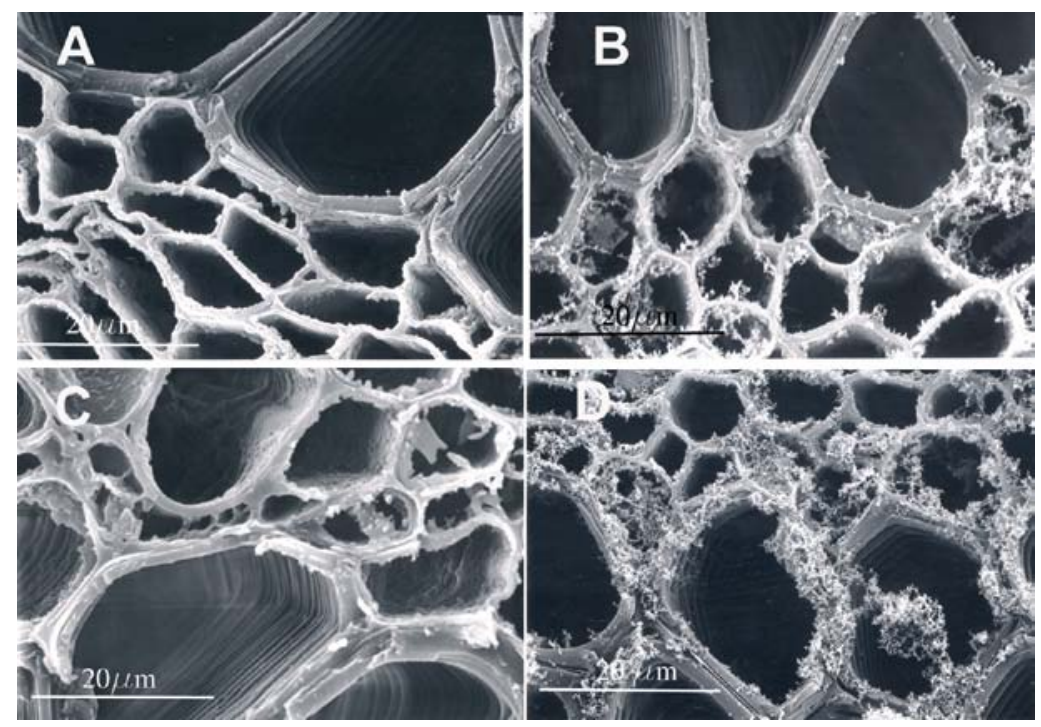

Figure 4. SEM micrographs showing the transverse section of stem (A, B) and root (C, D) of control (T0) and AsT2-treated fern plants, respectively. Clotted depositions were seen in AsT2 treated stems (B) and roots (D) compared to controls (A, C).
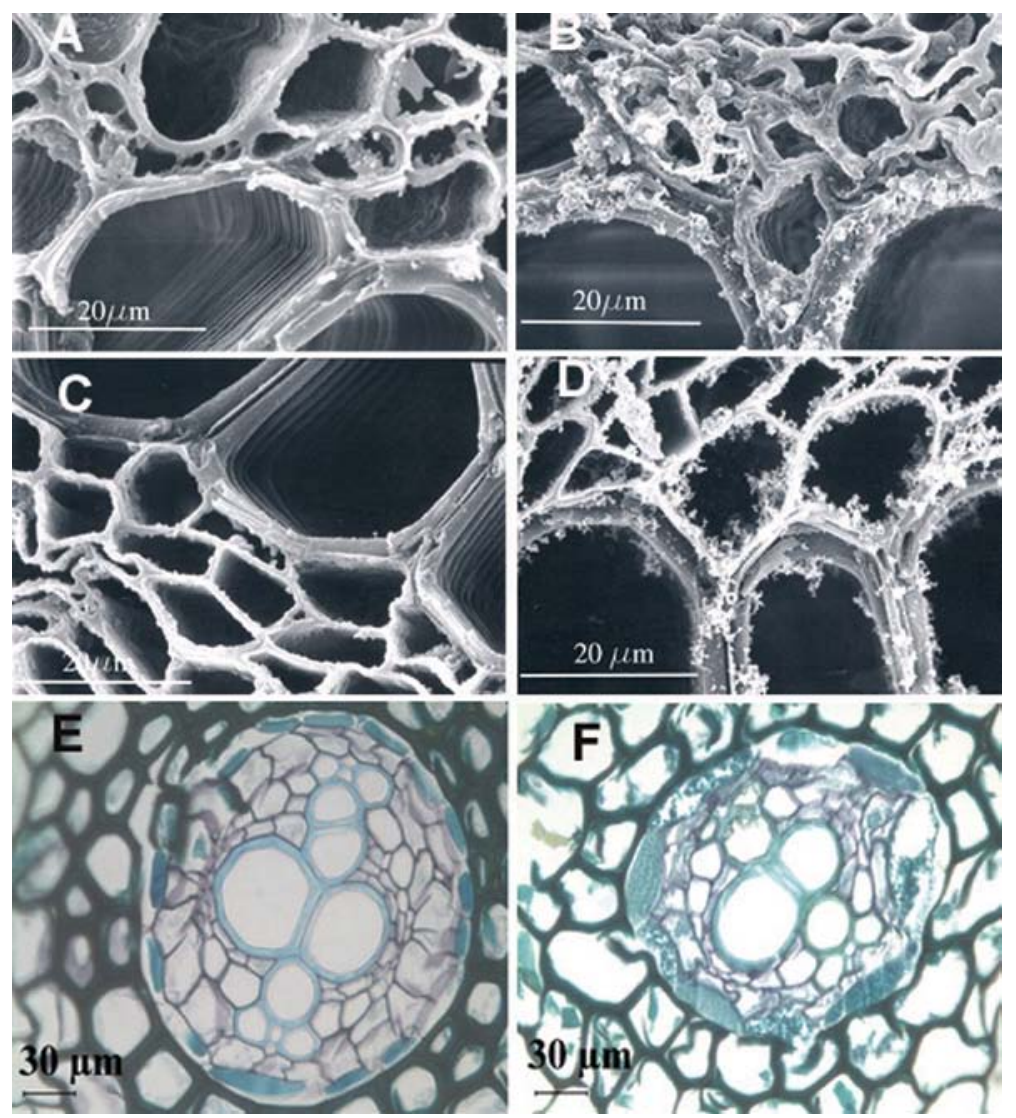

Figure 5. SEM micrographs and light micrographs showing the transverse section of stem (A, B) and root (C, D, E, F) of control (T0), CrT2- treated plants, respectively. The CrT2-(B) treated stems showed thickened xylem and phloem cell walls compared to control (A). Similarly the roots of CrT2-(D) treated plants showed clotted depositions along the walls of vascular bundles compared to control (C). Also note the breakdown of cortex and endodermal cells of CrT2-(F) treated roots compared to control (E) as shown by the light micrographs. 
Significant accumulation of As in shoots and the high shoot/root ratios indicates a high uptake, translocation and accumulation efficiency of brake fern plants for As. In our study, no significant changes in the ferns physical characters, including fresh weight, dry weight, RWC, and plant height were observed for As-accumulating plants. This is consistent with the fact that brake fern is a hyperaccumulator of As, identified by Ma et al. (2001). The only ultrastructural change observed was loss of the spindle shape of chloroplasts in lower palisade cells of leaves for AsT2-treated plants. The accumulated As was localized by SEM and LM as black depositions along the walls of vascular bundles of stems. Similar deposits were also seen in roots, but were less intense. The precipitates suggest a possible mechanism of detoxification of As in stems and roots.

The higher concentration treatment of $\mathrm{Cr}$ resulted in an increased accumulation in the roots followed by the shoots. The average chromium accumulation in shoots and roots of CrT2 treated plants are 2108 and 7686 ppm (mg kg-1 dry weight) respectively after three weeks of metal treatment (Table 2). Our results here indicate that even though brake fern cannot hyperaccumulate $\mathrm{Cr}$ as it does with As, it can accumulate $\mathrm{Cr}$ at high concentrations in the stems and roots and hence can be used for phytoremediation of Cr-contaminated soils. The decrease in fresh weight and dry weight indicates a decrease in plant growth rate and biomass with $\mathrm{Cr}$ accumulation. The decrease in RWC (Table 2) of the Cr accumulating plants and highly significant negative correlation of RWC (Table 3 ) with both shoot and root $(p<0.001) \mathrm{Cr}$ concentration, indicates that $\mathrm{Cr}$ accumulation resulted in water stress. This is further confirmed by the light micrographs of roots, which show break down of endodermal and cortical cells (Figure 5F). The high $\mathrm{Cr}$ concentration in roots resulted in cellular break down, affecting water and metal uptake. Vazquez et al. (1987) and Barcelo et al. (1986) showed that $\mathrm{Cr}$ caused severe injury to bush bean roots resulting in cellular plasmolysis and water stress. The decrease of leaf thickness (Table 2) may be due to $\mathrm{Cr}$ accumulation in leaves or due to $\mathrm{Cr}$-induced water stress or the combination of both.

In Cr-treated plants, significant amounts of precipitates were seen along the cell walls of the roots. The LM micrographs of roots showed breakdown of endodermal and cortical cells. These changes can be attributed to the intense oxidative action of $\mathrm{Cr}(\mathrm{VI})$, which was available to the roots.
The stems showed thickened cell walls and a decrease in the lumen size of xylem and phloem vessels. These effects of $\mathrm{Cr}$ (VI) were similar to as reported by Vazquez et al. (1987) in bush bean plants and Han et al. (2004) in mustard plants. The decreased vessel size in stems and cellular breakdown of roots may have resulted in the observed low shoot/root ratios and low translocation efficiency of $\mathrm{Cr}$. The leaves of Cr-treated plants also showed structural changes such as a decrease in intercellular spaces and shrinkage of epidermal, palisade and spongy parenchyma cells.

In our study, the Cr-treated plants accumulated significant $\mathrm{Cr}$ concentrations in both the shoots (upto $2108 \mathrm{mg} / \mathrm{kg}$ ) and roots (upto $7686 \mathrm{mg} / \mathrm{kg}$ ) and did not die immediately from phytotoxicity. The $\mathrm{Cr}$ accumulations reported in this study were higher compared to the $\mathrm{Cr}(\mathrm{VI})$ accumulations reported by Su et al. (2005) where brake fern plants accumulated up to $1,145 \mathrm{mg} / \mathrm{kg}$ in shoots and $5,717 \mathrm{mg} / \mathrm{kg}$ in roots of $\mathrm{Cr}(\mathrm{Vl})$ treated plants. In the study of Su et al. (2005) the brake fern plants were grown on soils added with $\mathrm{Cr}$ (VI) but in this study the $\mathrm{Cr}(\mathrm{VI})$ was applied in readily available solution form to the plants. This indicates that the brake fern plants have potential to accumulate $\mathrm{Cr}(\mathrm{VI})$ at higher concentrations when the $\mathrm{Cr}$ is made available in the more soluble and readily available form to the plants.

The high translocation efficiency for As shows that brake fern can act as an hyperaccumulator for As. Clotted depositions in the vascular bundles of stem and roots in As-treated plants can be suggested as being adaptation and detoxification mechanisms of brake fern. The structural changes in leaves, stems and cellular break down of roots of Cr-treated plants indicate that $\mathrm{Cr}$ has a profound impact and damages the plant physiology. Consequently, Cr-accumulating brake fern plants exhibit slow growth and decreased biomass. However, as both As and $\mathrm{Cr}$ occur as co-contaminants in several polluted sites, brake fern plants can be used as potential plant for phytoremediation of both metal contaminants.

Acknowledgements: We acknowledge Mr. Dharmendra K. Singh, Mr. Cheng Wang, Mr. Shyam S. Balasubramaniam, and Mr. Thomas W. Hallmark, for their contributions to data collection and plant culture activities. The authors thank Ms. Yunju Xia, Mr. Dean Patterson, and Dr. Thomas Meaker of DIAL for their help in chemical analysis. We also thank Mr. Richard F. Kuklinski, Mr. William A. Monroe, Ms. Kay N. Milam for expert assistance in microscopy; Ms. Amanda M. Lawrence 
for help in sample processing, providing Microtome and other accessories. This work was supported by funding from U.S. Department of Energy through Cooperative Agreement DEFC26-98FT-40395.

\section{REFERENCES}

Baker AJM (1981) Accumulators and excluders strategies in the response of plants to heavy metals. J. Plant Nutr. 3:643-654.

Barcelo J, Poschenrieder CH, Gunse B (1986) Water relations in chromium VI treated bush bean plants (Phaseolous vulgaris L. cv. Contender) under both normal and water stress conditions. J. Exp. Bot. 37:178-187.

Barcelo J, Vazquez MD, Poschenrieder CH (1988) Cadmium induced structural and ultrastructural changes in the vascular system of bush bean stems. Bot. Acta. 101:254-261.

Bartlett RJ (1991) Chromium cycling in soils and water: links and methods. Environ. Health Perspect. 92:17-29.

Blaylock MJ, Huang JW (2000) Phytoextraction of metals. In Raskin I, Ensley BD, eds. Phytoremediation of toxic metals: using plants to clean the environment. John Wiley \& Sons. Inc., New York. pp. 53-71.

Han FX, Banin A, Su Y, Monts DL, Plodinec MJ, Kingery WL, Triplett GB (2002) Industrial age anthropogenic inputs of heavy metals into the pedosphere. Naturwissenschaften. 89: 497-504.

Han FX, Banin A (1997) Long-term transformations and redistribution of potentially toxic heavy metals in arid zone soils. I. under saturated conditions. Water Air Soil Pollut. 95: 399-423.

Han FX, Sridhar BBM, Monts DL, Su Y (2004) Phytoavailability and toxicity of trivalent and hexavalent chromium to Brassica juncea L. Czern. New Phytol. 169:489-499

Han FX, Su Y, Monts DL, Plodinec MJ, Banin A, Triplett GB (2003) Assessment of global industrial-age anthropogenic arsenic contamination. Naturwissenschaften. 90:395-401.

Jackson ML (1958) Soil chemical analysis. Prentice Hall, New Jersey.

Johansen DA (1940) Plant Microtechniques. McGraw-Hill, New York.

Losi ME, Amrhein C, Frankenberger WT (1994) Factors affecting chemical and biological reduction of $\mathrm{Cr}(\mathrm{VI})$ in soil. Environ. Toxicol. Chem. 13:17271735.

Lytle CM, Lytle FW, Yang N, Qian J, Hansen D, Zayed A, Terry N (1998) Reduction of $\mathrm{Cr}$ (VI) to $\mathrm{Cr}$ (III) by wetland plants: potential for in situ heavy metal detoxification. Environ. Sci. Technol. 32:3087-3097.

Ma LQ, Komar KM, Tu C, Zhang W, Cai Y, Kenelley ED (2001) A fern that hyperccumulates arsenic, Nature. 409:579.

Mei B, Puryear JD, Newton RJ (2002) Assessment of Cr tolerance and accumulation in selected plant species. Plant Soil. 247:223-231.
Pearse AGE (1972) Histochemsitry theoretical and applied. $3^{\text {rd }}$ edn. Baltimore: Williams and Wilkins.

Qiu JH, Zayed A, Zhu YL, Yu M, Terry N (1999) Phytoaccumulation of trace elements by wetland plants:III uptake and accumulationof ten trace elements by twelve plant species. J. Environ. Qual. 28:1448-1455.

Raskin I, Ensley BD (2000) Phytoremediation of toxic metals: using plants to clean the environment. John Wiley \& Sons. Inc., New York.

Reeves RD, Baker AJM (1984) Studies on metal uptake by plants from serpentine and non-serpentine populations of Thlaspi goesingense Halacsy (Cruciferae). New Phytol. 98:191-204.

Salt DE, Blaylock M, Kumar NPBA, Dushenkov V, Ensley BD, Chet I, Raskin I (1995) Phytoremediation: A novel strategy for the removal of toxic metals from the environment using plants. Biotechnology. 13:468-474.

Salt DE, Kramer U (2000) Mechanisms of metal hyperaccumulation in plants. In Raskin I, Ensley BD, eds. Phytoremediation of toxic metals: using plants to clean the environment. New York: John Wiley \& Sons. Inc. 231-247.

Salt DE, Smith RD, Raskin I (1998) Phytoremediation. Ann. Rev. Plant Physiol. Plant Mol. Biol. 49:643-668.

Sass JE (1958) Botanical microtechniques. lowa St. Univ Press, Ames.

Shahandeh H, Hossner LR (2000) Plant screening for chromium phytoremediation. Int. J. Phytorem. 2:31-51.

Sridhar BBM, Han FX, Diehl SV, Monts DL, Su Y (2007a) Effects of Zn and Cd accumulation on structural and physiological characteristics of barley plants. Braz. J. Plant Physiol. 19: 15-22.

Sridhar BBM, Han FX, Diehl SV, Monts DL, Su Y (2007b) Monitoring the effects of Arsenic- and Chromium- accumulation in Chinese brake fern (Pteris vittata) using microscopy and near infrared spectral reflectance. Int. J. of Remote Sens 28: 1055-1067.

Su Y, Han FX, Sridhar BBM, Monts DL (2005) Phytotoxicity and phytoaccumulation of trivalent and hexavalent chromium in brake fern Environ Toxicol Chem 24: 2019-2026.

Suzuki T, Sumi Y, Miyazaki K, Muraki T, Nokubi K, Kimura M, Kato M (1978) Histochemical staining of chromium by Azurol S. Acta Histochemica Et Cytochemica. 11:46-51.

Vazquez MD, Poschenreider C, Barcelo J (1987) Chromium VI induced structural and ultrastuctural changes in bush bean (Phaseolus vulgaris L.). Ann. Bot. 59:427-438

Witmer CM, Harris R, Shupak SI (1991) Oral bioavailability of chromium from a specific site. Environ. Health Perspect. 92:105-110.

Zayed A, Lytle CM, Qian J, Terry N (1998) Chromium accumulation, translocation and chemical speciation in vegetable crops, Planta. 206:293299.

Zhao FJ, Lombi E, Breedon T, McGrath SP (2000) Zinc hyperaccumulation and cellular distribution in Arabidopsis halleri, Plant Cell Environ. 23:507-514. 